\title{
Comparing Pre-Service Teachers' Self-Confidence Levels in Technological Pedagogical Content Knowledge in Terms of Several Variables
}

\author{
Erol Süzük ${ }^{1} \&$ Tuncay Akınci ${ }^{1}$ \\ ${ }^{1}$ Atatürk Faculty of Education, Marmara University, Istanbul, Turkey \\ Correspondence: Erol Süzük, Atatürk Faculty of Education, Marmara University, Istanbul, Turkey. E-mail: \\ erol.suzuk@marmara.edu.tr
}

Received: December 18, 2020 Accepted: January 18, 2021 Online Published: January 26, 2021

doi:10.5539/jel.v10n1p82 URL: https://doi.org/10.5539/jel.v10n1p82

Some part this study is presented as oral presentation in the "The 2nd International Conference on Language, Education, and Culture (ICLEC)" which was hosted by the Medipol University in Turkey, 27 to 29th June 2019.

\begin{abstract}
This study aimed to investigate and compare pre-service teachers' self-confidence in technological pedagogical content knowledge (TPACK) concerning their gender, department, and owned digital technologies. To achieve this goal, the survey method was conducted as part of a quantitative method design. Participants of the study consisted of 252 pre-service teachers from four different concentrations: physics, chemistry, biology, and german language teaching. TPACK Self Confidence Scale (TPACK-SCS), which was constructed by Graham, Burgoyne, Cantrell, Smith, and Harris (2009) and adapted to Turkish by Timur and Taşar (2011), was used as the data collection tool. TPACK-SCS is a scale with 4 sub-dimensions as Technological Pedagogical Content Knowledge (TPACK), Technological Pedagogical Knowledge (TPK), Technological Knowledge (TK), and Technological Content Knowledge (TCK). The Cronbach's Alpha internal reliability coefficients of the scale were calculated between .78 and .94 . Since the data obtained did not show normal distribution it was analyzed by Mann-Whitney U and Kruskal Wallis - $\mathrm{H}$ tests. According to the results, significant differences were found in the level of self-confidence and sub-dimensions of students' TPACK according to gender, department, and owned digital technologies for education.
\end{abstract}

Keywords: teacher education, technological pedagogical content knowledge, self-confidence

\section{Introduction}

\subsection{The Problem and Research Questions}

Within the framework of the great technological development and social change that emerged in the twenty-first century (MOE, 2017), the curricula which were updated at various times before were lastly updated by the Ministry of National Education in 2018. The most recently updated curriculum aims to empower students to gather eight key competencies specified in the Turkey Competencies Framework (MOE, 2018). These competencies are:

1) Digital competence.

2) Communication in the mother tongue,

3) Communication in foreign languages,

4) Mathematical competence and basic competencies in science/technology,

5) Learning to learn,

6) Social and civic competencies,

7) Taking initiative and entrepreneurship,

8) Cultural awareness and expression

Digital competence defined by MOE (2008) as: 
"It covers the safe and critical use of information communication technologies for business, daily life, and communication. This competence is supported through basic skills such as access to information and the use of computers for the evaluation, storage, production, presentation and exchange of information, as well as participation in common networks and communication through the Internet."

In this context, teachers who are the implementers of the curriculum are expected to have digital competence. However, recent studies show that teachers have not been prepared enough to bring these technologies into their classrooms effectively, despite major investments in technology and teaching (Angeli \& Valanides, 2009; Ertmer \& Ottenbreit-Leftwich, 2010; Agyei \& Voogt, 2012). Even the twenty-first century pre-service teachers, who are defined as digital indigenous, are not sure how to integrate instructional technologies with learning and teaching activities (Uygun, 2013). When we dip into the history of educational technology, it is seen that, in the beginning, teacher candidates were given only technological training in their teaching programs and they were not informed about how to bring this technology into teaching effectively (Graham et al., 2009; Graham, Culatta, Pratt, \& West, 2004). It is not so easy to successfully integrate technology into teaching for teachers (Jang \& Tsai, 2012). Studies show that teachers do not draw on technology in their lessons according to expectations (Ertmer \& Ottenbreit-Leftwich, 2010; Ertmer et al., 1999). Furthermore, if teachers do not trust themselves to support their students' learning, their knowledge of technology will become insufficient (Ertmer \& Ottenbreit-Leftwich, 2010) since a teacher's confidence in the utilization of technology can impact the effective usage of technology in the classroom (Christanse, 2002). Besides, the utilization of technology in education is strongly influenced by the content area (Graham et al., 2009), and for effective technology integration, teachers' experience with technology must be specific to the content area (Schmidt et al., 2009).

In this manner, this research study intends to compare self-confidence levels of pre-service teachers in TPACK. The sub-questions of the research based on the relevant literature are as follows:

1) Do the pre-service teachers' self-confidence levels in TPACK differ according to gender?

2) Do the pre-service teachers' self-confidence levels in TPACK differ according to the department?

3) Do the pre-service teachers' self-confidence levels in TPACK differ according to used digital technologies for education?

\subsection{Theoretical Framework}

In addition to technology teaching, in 2006, Mishra and Koehler claimed the conceptual framework of Technological Pedagogical Content Knowledge (TPCK) for how to merge technology into teaching to enable students to learn more effectively (Mishra \& Koehler, 2006). Mishra and Koehler (2006) argue that new information technologies change the classroom environment. They propose a new framework built on Shulman's pedagogical content knowledge (PCK). They argue that Technology Knowledge (TK) is critical for effective teaching and so they integrated PCK with TK which resulted in technological pedagogical content knowledge (TPCK). The abbreviation TPCK was later altered to TPACK with the opinion that the PK, CK, and TK fields together were Total Package (Thompson \& Mishra, 2007). Technological Pedagogical Content Knowledge (TPACK) comprises of seven sub-fields (Figure 1).

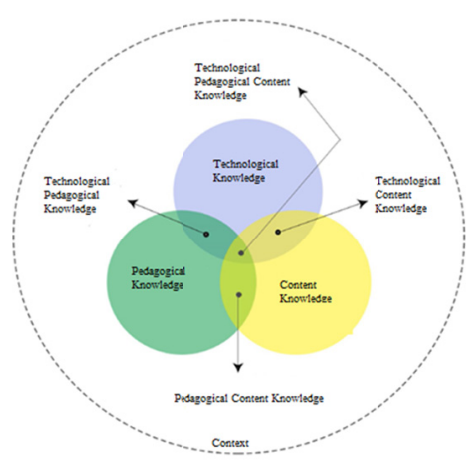

Figure 1. TPACK framework

As seen in Figure 1, these sub fields are described briefly at the below:

1) Technological Knowledge (TK): Knowledge about how to use a computer and other technological tools and 
software

2) Pedagogical Knowledge (PB): Knowledge of planning, presenting, evaluating and managing individual differences in the classroom

3) Content Knowledge (CK): Having knowledge specific to a field such as Physics, Chemistry, Biology, Mathematics and Language

4) Technological Content Information (TCK): Information on which technological tools or software can be presented to a specific subject

5) Pedagogical Content Knowledge (PCK): Information on how to better present topics specific to a field

6) Technological Pedagogical Knowledge (TPK): Knowledge of how technology can better support pedagogy

7) Technological Pedagogical Content Knowledge (TPACK): Knowledge of helping students by using appropriate pedagogy and technology in teaching specific subjects in a field.

\section{Method}

\subsection{Research Design}

In this study, a cross-sectional survey research method was used for a retrospective inquiry. A cross-sectional study is a study that produces a 'snapshot' of a population at a particular point during a retrospective or pre-service inquiry, while also allowing comparison of different groups (Cohen et al., 2018). According to Creswell (2011), one of the cross-sectional designs in educational research is to compare two or more educational groups in terms of attitudes, beliefs, opinions, or groups. As this study intends to compare self-confidence levels of pre-service teachers in TPACK, cross-sectional design is used.

\subsection{Study Group}

There are 252 pre-service teachers in the study group. They were studying at Physics, Chemistry, Biology, and German Language Teaching Programs of a big-sized university in Turkey. The candidates were explained the scope of the research at the beginning of the study, and the volunteers were studied. Data of the study were gained from the participants at spring semester 2019. The distribution of teacher candidates according to their gender and departments is presented in Table 1.

Table 1. Characteristics of teacher candidates participating in the research

\begin{tabular}{llll}
\hline Department & Male & Female & Total \\
\hline Physics Teaching & 13 & 43 & 56 \\
Chemistry Teaching & 5 & 51 & 56 \\
Biology Teaching & 14 & 58 & 72 \\
German Language Teaching & 22 & 46 & 68 \\
Total & 54 & 198 & 252 \\
\hline
\end{tabular}

\subsection{Data Collection Tools}

In this study, the TPACK self-confidence scale (TPACK-SCS) was used to determine the self-confidence levels of pre-service teachers in TPACK. TPACK-SCS was developed by Graham et al. (2009) and adapted to Turkish by Timur and Taşar (2011). The original TPACK-SCS is a six-point Likert-type scale consisting of 4 subscales (Technological Pedagogical Content Knowledge (TPACK), Technological Pedagogical Knowledge (TPK), Technological Content Knowledge (TCK), and Technological Knowledge (TK)) and 31 items. The original scale was developed with 50 science teachers. There were no negative items on the scale. The researchers did not investigate the construct validity because the number of samples was not sufficient. Graham et al. (2009) reported that Cronbach Alpha internal consistency coefficients for the sub-dimensions of the scale were $\alpha=.951$ for TPACK, $\alpha=.913$ for TPK, $\alpha=.971$ for TCK and $\alpha=.922$ for TK (Graham et al., 2009).

Timur and Taşar (2011) adapted the scale to Turkish using a 5-point rating. They concluded that the structure of the original 4-factor scale was also preserved in Turkish culture through a confirmatory factor analysis. Cronbach's Alpha reliability coefficient was $\alpha=.93$ for the whole scale; $\alpha=.91$ for TPACK dimension, $\alpha=.87$ for TPK dimension, $\alpha=.94$ for TCK dimension and $\alpha=.94$ for TK dimension (Timur \& Taşar, 2011).

In this study, Cronbach's alpha reliability coefficient was computed as $\alpha=.92$ for the whole scale; $\alpha=.89$ for TPACK dimension, $\alpha=.78$ for TPK dimension, $\alpha=.89$ for TCK dimension and $\alpha=.89$ for TK dimension. 
Besides, the information about pre-service teachers' gender, department, owned digital technologies, and digital technologies' usage level were collected through the Personal Information Form prepared by the researchers.

\subsection{Data Analysis}

The normality test was conducted to determine whether it shows normal distribution or not. Since the data obtained did not show normal distribution it was analyzed by Mann-Whitney U and Kruskal Wallis-H tests. SPSS was used to conduct the tests.

Moreover, effect sizes are calculated in order to interpret the practical meanings of the results obtained. The effect size is a measure of how big the effect is between the two groups, which is something that statistical significance does not tell us. The effect sizes obtained were construed as $\mathrm{r}=.20$ "small", $\mathrm{r}=.50$ "medium" and $\mathrm{r}$ $=.80$ "large" (Cohen, Manion, \& Morrison, 2018).

To compare the scores of the pre-service teachers' TPACK and subscales comparatively, the total scores of each scale were divided into item numbers and converted to 6-point ratings. The following score ranges and corresponding confidence levels were used to interpret these mean scores.

Table 2. Points ranges used for interpreting TPACK qualification points

\begin{tabular}{ll}
\hline Score Range & Confidence Level \\
\hline $0-0.85$ & I don't trust at all. \\
$0.86-1.68$ & I trust little. \\
$1.69-2.51$ & I trust at a moderate level. \\
$2.52-3.34$ & I trust quite a bit. \\
$3.35-4.17$ & I trust a lot \\
$4.18-5.00$ & I totally trust. \\
\hline
\end{tabular}

\section{Results}

First of all, the Kolmogorov-Smirnov test was used to determine whether the pre-service teachers had normal distribution characteristics before testing their TPACK self-confidence and subscale scores according to their demographic variables. The result of the Kolmogorov-Smirnov test is shown in Table 3.

Table 3. Kolmogorov-Smirnov test for distribution of sample

\begin{tabular}{llll}
\hline Scale & Statistic & df & Sig. \\
\hline TPACK-SCS & .089 & 230 & .000 \\
TPACK & .125 & 230 & .000 \\
TCK & .153 & 230 & .000 \\
TK & .118 & 230 & .000 \\
TPK & .135 & 230 & .000 \\
\hline
\end{tabular}

When we look at Table 3, the Kolmogorov-Smirnov test shows that the distribution of the sample did not meet the assumption of normality for the TPACK self-confidence scale and the subscales. Therefore, non-parametric tests (Mann-Whitney U and Kruskal Wallis-H) were used to determine whether the scores of the TPACK self-confidence scale and subscales differed according to various demographic variables.

\subsection{Pre-Service Teachers' Perceptions of TPACK Confidence Level}

Table 4 shows the findings related to the level of confidence in TPACK of pre-service teachers. 
Table 4. Pre-service teachers' TPACK confidence levels

\begin{tabular}{llllll}
\hline Scale & Department & $\mathrm{N}$ & $\overline{\mathbf{X}}$ & $\mathrm{SD}$ & Confidence Level \\
\hline TPACK-SCS & Physics Teaching & 49 & 3.91 & .71 & I trust a lot \\
& Chemistry Teaching & 54 & 3.82 & .55 & I trust a lot \\
& Biology Teaching & 59 & 3.67 & .72 & I trust a lot \\
& German Language Teaching & 68 & 3.89 & .49 & I trust a lot \\
TPACK & Total & 230 & 3.82 & .62 & I trust a lot \\
& Physics Teaching & 56 & 4.22 & .72 & I totally trust \\
& Chemistry Teaching & 56 & 4.08 & .62 & I trust a lot \\
& Biology Teaching & 70 & 3.84 & .83 & I trust a lot \\
TCK & German Language Teaching & 68 & 4.09 & .65 & I trust a lot \\
& Total & 250 & 4.05 & .72 & I trust a lot \\
& Physics Teaching & 55 & 3.7 & 1.22 & I trust a lot \\
& Chemistry Teaching & 55 & 3.44 & 1.37 & I trust a lot \\
& Biology Teaching & 70 & 3.31 & 1.26 & I trust a lot \\
& German Language Teaching & 68 & 2.93 & 1.7 & I trust a lot \\
& Total & 248 & 3.32 & 1.43 & I trust a lot \\
& Physics Teaching & 50 & 3.95 & .88 & I trust a lot \\
& Chemistry Teaching & 55 & 4.02 & .65 & I trust a lot \\
& Biology Teaching & 64 & 3.87 & .78 & I trust a lot \\
& German Language Teaching & 68 & 4.31 & .46 & I totally trust \\
& Total & 237 & 4.05 & .71 & I trust a lot \\
& Physics Teaching & 55 & 4.25 & .75 & I totally trust \\
& Chemistry Teaching & 56 & 4.11 & .58 & I trust a lot \\
& Biology Teaching & 67 & 4.01 & .84 & I trust a lot \\
& German Language Teaching & 68 & 4.32 & .78 & I totally trust \\
& Total & 246 & 4.17 & .75 & I trust a lot \\
\hline \multirow{4}{*}{ TPK } & & & &
\end{tabular}

According to the results of descriptive analysis, it was seen from Table 4 that the overall average scores of the teacher candidates' TPACK confidence levels were $\bar{x}=3.82$. Accordingly, the average score of the candidates for the overall scale is "I trust a lot". In the sub-dimensions, it was determined that the scores ranged between 3.32 and 4.17 on average. The average of the scores obtained from the sub-dimensions corresponds to "I trust a lot" for all sub-scales.

When the confidence levels of the pre-service teachers are inspected in detail according to their departments, it can be remarked that physics teaching pre-service teachers trust them in TPACK and TPK dimensions, and German teaching pre-service teachers trust TK and TPK dimensions at the highest level which is "I totally trust".

\subsection{Pre-Service Teachers' TPACK Confidence Levels Difference According to Gender Variable}

The first sub-problem of this research is "Do the pre-service teachers' TPACK self-confidence differ according to gender?

The Mann-Whitney U test was conducted to find the answer to the above problem. The result obtained is shown in the Table 5. 
Table 5. Mann Whitney U test result for gender variable

\begin{tabular}{llllll}
\hline Scale & $\mathrm{N}$ & Mean Rank & $\mathrm{U}$ & $\mathrm{z}$ & $\mathbf{p}$ \\
\hline TPACK-SCS & 181 & 155.55 & & & .98 \\
$\begin{array}{l}\text { Female } \\
\text { Male }\end{array}$ & 49 & 115.31 & & & \\
Total & 230 & & 4425 & -0 & \\
TPACK & & & & .32 \\
Female & 197 & 127.85 & & & \\
Male & 53 & 116.77 & 4758 & -1 & \\
Total & 250 & & & & .53 \\
TCK & & & & & \\
Female & 195 & 123.02 & 5456 & .63 & \\
Male & 53 & 129.94 & & & .53 \\
Total & 248 & & & & \\
TK & & & & \\
Female & 187 & 117.56 & 4943.5 & .62 & \\
Male & 50 & 124.37 & & & .02 \\
Total & 237 & & & & \\
TPK & & & & \\
Female & 193 & 129.00 & & & \\
Male & 53 & 103.46 & & & \\
Total & 246 & & & & \\
\hline
\end{tabular}

Table 5 shows that Mann Whitney U results for the first sub-problem. When we look at the p-value of pre-service teachers' TPACK self-confidence scores and TPACK, TCK, and TK sub-scale scores, they did not differ according to gender $(\mathrm{p}>.05)$. On the other hand, there was a significant difference between females and males at TPK scores and this difference was in the favor of females $(p=.02$ and $p<.05)$.

The effect size of the difference between females and males in the TPK dimension was found by the formula $r=$ $\mathrm{z} / \sqrt{\mathrm{N}}$ for $\mathrm{z}$ value and calculated as $\mathrm{r}=.15$. It can be said that gender has a small effect on the confidence levels of the candidates in the TPK dimension.

\subsection{Pre-Service Teachers' TPACK Confidence Levels Difference According to Department Variable}

The second sub-problem of the research is "Do the pre-service teachers' TPACK self-confidence differ according to the department?"

The Kruskal Wallis $\mathrm{H}$ test was conducted to find the answer to the second sub-problem. The result obtained is shown in the Table 6.

Table 6. Kruskal Wallis $-\mathrm{H}$ test result for department variable

\begin{tabular}{llllll}
\hline Scale & Groups & Mean Rank & Test Result & df & $\mathrm{p}$ \\
\hline TPACK-SCS & Physics Teaching & 49 & 129.69 & 5.29 & .15 \\
& Chemistry Teaching & 54 & 112.58 & & \\
& Biology Teaching & 59 & 101.37 & & \\
TPACK & German Language Teaching & 68 & 119.85 & & \\
& Physics Teaching & 56 & 144.94 & 8.02 & .046 \\
& Chemistry Teaching & 56 & 124.62 & & \\
& Biology Teaching & 70 & 108.51 & & \\
TCK & German Language Teaching & 68 & 129.71 & & \\
& Physics Teaching & 55 & 142.03 & 6.49 & .9 \\
& Chemistry Teaching & 55 & 131.11 & & \\
TK & Biology Teaching & 70 & 117.71 & & \\
& German Language Teaching & 68 & 11.97 & & \\
& Physics Teaching & 50 & 115.17 & 11.86 & .008 \\
& Chemistry Teaching & 55 & 113.43 & & \\
TPK & Biology Teaching & 64 & 102.45 & & \\
& German Language Teaching & 68 & 141.9 & & \\
& Physics Teaching & 55 & 135.66 & 5.16 & .16 \\
& Chemistry Teaching & 56 & 114.46 & & \\
& Biology Teaching & 67 & 112.42 & & \\
\hline
\end{tabular}


When we look at Table 6, Kruskal Wallis H results show that pre-service teachers' TPACK self-confidence scores differ according to the department in TPACK and TK subscales $(p<.05)$. To find out the difference between the departments, the Mann-Whitney $U$ test was performed between the departments.

Table 7 shows the results of Mann-Whitney U analysis between departments for TPACK sub-scale scores.

Table 7. Post-Hoc Mann Whitney U test result for TPACK sub-scale

\begin{tabular}{|c|c|c|c|c|}
\hline Department & $\mathrm{U}$ & $\mathrm{z}$ & $\mathrm{p}$ & \\
\hline Biology - Chemistry & 16.109 & 1.245 & 1.000 & \\
\hline Biology Teaching & & & & 108.51 \\
\hline Chemistry Teaching & & & & 124.62 \\
\hline Biology - German Language & -19.206 & -1.563 & .708 & \\
\hline Biology Teaching & & & & 108.51 \\
\hline German Language Teaching & & & & 127.71 \\
\hline Biology - Physics & 36.430 & 2.816 & .029 & \\
\hline Biology Teaching & & & & 108.51 \\
\hline Physics Teaching & & & & 144.94 \\
\hline Chemistry - German Language & -3.097 & -.238 & 1.000 & \\
\hline Chemistry Teaching & & & & 124.62 \\
\hline German Language Teaching & & & & 127.71 \\
\hline Chemistry - Physics & 20.321 & 1.490 & .817 & \\
\hline Chemistry Teaching & & & & 124.62 \\
\hline Physics Teaching & & & & 144.94 \\
\hline German Language - Physics & 17.224 & 1.323 & 1.000 & \\
\hline German Language Teaching & & & & 127.71 \\
\hline Physics Teaching & & & & 144.94 \\
\hline
\end{tabular}

Table 7 shows that Mann Whitney U results for the differentiation of the scores of the candidates on the TPACK sub-scale according to the department. When we look at the p-value of pre-service teachers' TPACK sub-scale scores, there was a significant difference between biology and physics candidates' TPACK sub-scale scores and this difference was in the favor of physics pre-service teachers $(\mathrm{p}=.029$ and $\mathrm{p}<.05)$.

The effect size of the difference between biology and physics pre-service teachers in TPACK sub-dimension was found by the formula $\mathrm{r}=\mathrm{Z} / \sqrt{\mathrm{N}}$ for $\mathrm{z}$ value and calculated as $\mathrm{r}=.25$. It can be said that the department has a small effect on the confidence levels of the candidates in the TPACK sub-dimension for biology and physics pre-service teachers.

Table 8 shows the results of Mann-Whitney U analysis between departments for TK sub-scale scores.

Table 8. Post-Hoc Mann Whitney U test result for TK sub-scale

\begin{tabular}{lllll}
\hline Department & $\mathrm{U}$ & $\mathrm{z}$ & $\mathrm{p}$ & \\
\hline $\begin{array}{l}\text { Biology - Chemistry } \\
\text { Biology Teaching }\end{array}$ & 10.974 & .872 & 1.000 & \\
$\begin{array}{l}\text { Chemistry Teaching } \\
\text { Biology - German Language }\end{array}$ & & & & 102.45 \\
$\begin{array}{l}\text { Biology Teaching } \\
\text { German Language Teaching }\end{array}$ & -39.444 & -3.308 & -.006 & 113.43 \\
$\begin{array}{l}\text { Biology - Physics } \\
\text { Biology Teaching }\end{array}$ & 12.717 & .984 & 1.000 & 102.45 \\
$\begin{array}{l}\text { Physics Teaching } \\
\text { Chemistry - German Language }\end{array}$ & -28.470 & -2.293 & .131 & 141.9 \\
$\begin{array}{l}\text { Chemistry Teaching } \\
\text { German Language Teaching }\end{array}$ & & & & 102.45 \\
Chemistry - Physics & & & & 115.17 \\
Chemistry Teaching & 1.743 & .130 & 1.000 & 113.43 \\
$\begin{array}{l}\text { Physics Teaching } \\
\text { German Language - Physics }\end{array}$ & & & & 113.43 \\
German Language Teaching & -26.723 & -2.095 & .217 & 115.17 \\
Physics Teaching & & & & 141.9 \\
\hline
\end{tabular}


Table 8 shows that Mann Whitney U results for the differentiation of the scores of the candidates on the TK sub-scale related to the department. When we look at the p-value of pre-service teachers' TK sub-scale scores, there was a significant difference between biology and german language candidates' TK sub-scale scores and this difference was in the favor of german language pre-service teachers $(p=.029$ and $p<.05)$.

The effect size of the difference between biology and german language pre-service teachers in the TK sub-dimension was found by the formula $r=Z / \sqrt{N}$ for $z$ value and calculated as $r=0.28$. It can be said that the department has a small effect on the confidence levels of the candidates in the TK sub-dimension for biology and german language candidates.

\subsection{Pre-Service Teachers' TPACK Confidence Levels Difference According to Used Digital Technologies for Education Variable}

The third sub-problem of the study is "Do the pre-service teachers' TPACK self-confidence differ according to used digital technologies for education?"

The Mann-Whitney U test was conducted to find the answer and the result obtained is shown in the table 9 .

Table 9. Mann Whitney U Test Result for Used Digital Technologies for Education Variable

\begin{tabular}{lllll}
\hline Used Technology & Scale & $\mathrm{U}$ & $\mathrm{z}$ & $\mathrm{p}$ \\
\hline Mobile Phone & TPACK-SCS & 988.500 & -.031 & .976 \\
& TPACK & 896.500 & -.884 & .376 \\
& TCK & 1021.500 & -.256 & .798 \\
& TK & 967.500 & -.290 & .772 \\
Desktop Computer & TPK & 1054.000 & -.060 & .952 \\
& TPACK-SCS & 4181.500 & -.765 & .444 \\
& TPACK & 5441.500 & -.123 & .902 \\
& TCK & 5042.000 & -.709 & .478 \\
Laptop Computer & TK & 4176.000 & -1.594 & .111 \\
& TPK & 4924.000 & -.710 & .478 \\
& TPACK-SCS & 2810.000 & -3.231 & .001 \\
& TPACK & 3291.500 & -3.743 & .000 \\
Tablet & TCK & 4871.000 & -.010 & .992 \\
& TK & 2986.500 & -3.658 & .001 \\
& TPK & 3205.500 & -3.512 & .001 \\
& TPACK-SCS & 4332.000 & -2.064 & .039 \\
& TPACK & 4754.000 & -2.724 & .006 \\
& TCK & 5507.000 & -1.002 & .316 \\
& TK & 4634.500 & -1.926 & .054 \\
& TPK & 5767.000 & -.573 & .566 \\
\hline
\end{tabular}

Table 9 shows that Mann Whitney U results for the differentiation of the scores of the candidates on the scales related to used digital technologies for education. When we glance at the p-value of pre-service teachers' TPACK self-confidence and TPACK, TCK, and TK sub-scale scores, they did not differ according to mobile phones and desktop computers $(\mathrm{p}>.05)$. However, there were significant differences for laptop computer variable at TPACK self-confidence and TPACK, TK, and TPK sub-scale scores $(p<.05)$. The pre-service teachers who use their laptops for their classes have higher scores at TPACK self-confidence and TPACK, TK, and TPK sub-scale than those who do not have. Again, there are similar results for tablet computers. There was a significant difference for the tablet computer variable at TPACK self-confidence and TPACK and TK sub-scale scores $(\mathrm{p}<.05)$. The pre-service teachers who use their tablets for their classes have higher scores at TPACK self-confidence and TPACK, and TK sub-scale than those who do not have.

However, the effect sizes calculated for the above significant differences are between .17 and .24 and so they are all small effect sizes. This means that even preservice teachers who use laptops and tablets for their classes have a significant and positive difference than those who do not, it can be said that using laptops and tablets for classes has a small effect on the confidence levels of the pre-service teachers.

\section{Discussion and Conclusion}

In this study, it was aimed to investigate and compare pre-service teachers' self-confidence in TPACK according to the variables of gender, department, and used digital technologies. A total of 252 preservice teachers attending 
at physics, chemistry, biology, and german language teaching programs participated in the study. Data were obtained through a TPACK self-confidence scale constructed by Graham et al. (2009) and translated and validated into Turkish by Timur and Taşar (2011). The results pointed out that the candidate teachers have high self-confidence (I trust a lot) level in all domains. This finding is similar to the findings of Raman (2014) and Açıkgül and Aslaner (2015), Al-Abdullatif (2019), and Rahmadi, Hayati, and Nursyifa (2020). They indicated in their studies that pre-service teachers have enough confidence in themselves in all domains. This result can be interpreted as positive since teachers need to trust themselves to use technology in their courses.

The effect of gender on pre-service teachers' TPACK domains was also investigated. There was a statistically significant difference in the TPB-self-confidence subscale in favor of female students according to gender variable, but no significant difference was found in other sub-dimensions and the whole scale. There were no significant differences in TPACK self-confidence dimension in terms of gender in the related literature (Al-Abdullatif, 2019; Akgündüz \& Bağdiken, 2018; Erzengin, 2017; Karakaya \& Avgin, 2016; Göl, 2016; Açıkgül \& Arslaner, 2015; Meriç, 2014; Öztürk, 2013; Tokmak et al., 2013; Mutluoglu, 2012; Koh \& Chai, 2011).

However, Akyıldız and Altun (2018), Altunoğlu (2018), Bağrıyanık (2015), and Karadeniz and Vatanartıran (2015) in the dimension of TPACK self-confidence and Koh, et al. (2010), Gömleksiz and Fidan (2011), and Kazu and Erten (2011) found significant differences in some sub-dimensions according to gender. For example, Koh et al. (2010), in their studies with 1185 pre-service teachers, stated that gender is an effective factor in terms of technology knowledge, content knowledge, and technological pedagogical knowledge. In the TPACK self-confidence dimension, Bağrıyanık (2015) and Altunoğlu (2018) were in favor of male teachers; Akylldız and Altun (2018) found a significant difference in favor of women. These different results show that gender is not a dominant independent variable in terms of TPACK dimensions (Tuncer \& Dikmen, 2018).

The results also showed that the department had a significant effect on pre-service teachers' TPACK scores only in TPACK and TB self-confidence sub-dimensions. The reason for this difference may be due to the experiences of the pre-service teachers in the related departments in using technology in teaching processes. For instance, Jang and Tsai (2012) stated that pre-service mathematics teachers had lower TPACK scores than science teachers, and that science teachers used technological tools and methods more frequently in their classes. Also, Tokmak, et al. (2013) found that there were differences between TPACKs of pre-service teachers in different departments.

When self-confidence scores of the pre-service teachers in TPACK according to used digital technologies for their classes were examined, a statistically significant difference was seen between the pre-service teachers who had laptop or tablet computers. In the related literature, Açıkgül and Aslaner (2015) and Tokmak et al. (2013) stated that students who have computers have higher TPACK self-confidence.

Based on the study findings, the following policy recommendations will be proposed:

. Pre-service teachers' high level of confidence in TPACK shows that they have the basic competencies to use technology in their education. So, it may be important to train teachers who can adapt to new technologies that may arise in the future. Otherwise, it will be inevitable that the investments to be made in this context will be wasted.

. To teach today's digital natives, it is important that teachers should be educated as digitally competent teachers.

. Similar studies in other teaching departments are recommended for the purpose of generalization of findings.

. In this study, the pre-service teachers' beliefs on confidence levels in TPACK were only investigated, in future studies, how they implement their beliefs into practice should also be explored.

. TPACK confidence levels of pre-service teachers were investigated using only quantitative method. In order to fully understand TPACK confidence levels, qualitative methods should be used also.

\section{References}

Açıkgül, K., \& Aslaner, R. (2015). İlköğretim matematik öğretmen adaylarının tpab güven algılarının incelenmesi. Erzincan Üniversitesi Eğitim Fakültesi Dergisi, 17(1), 118-152. https://doi.org/10.17556/jef.04990

Agyei, D. D., \& Voogt, J. (2012). Developing technological pedagogical content knowledge in pre-service mathematics teachers through collaborative design. Australasian Journal of Educational Technology, 28(4). https://doi.org/10.14742/ajet.827

Akgündüz, D., \& Bağdiken, P. (2018). Fen bilimleri öğretmenlerinin teknolojik pedagojik alan bilgisi özgüven 
düzeylerinin incelenmesi. Gazi Üniversitesi Gazi Eğitim Fakültesi Dergisi, 38(2), 535-566. https://doi.org/10.17152/gefad.357224

Akyıldız, S., \& Altun, T. (2018). Sınıf öğretmeni adaylarının teknolojik pedagojik alan bilgilerinin (tpab) bazı değişkenlere göre incelenmesi. Journal of Education, 8(2), 318-333. https://doi.org/10.24315/trkefd.322749

Al-Abdullatif, A. M. (2019). Auditing the TPACK confidence of pre-service teachers: The case of Saudi Arabia. Education and Information Technologies, 24, 3393-3413. https://doi.org/10.1007/s10639-019-09924-0

Altunoğlu, A. (2018). Fen bilimleri ögretmenlerinin teknolojik pedagojik alan bilgisi (TPAB) düzeyleri ve teknolojiye yönelik tutumlarının incelenmesi. Yayımlanmamış yüksek lisans tezi. Cumhuriyet Üniversitesi, Eğitim Bilimleri Enstitüsü, Sivas.

Angeli, C., \& Valanides, N. (2009). Epistemological and methodological issues for the conceptualization, development, and assessment of ICT-TPCK: Advances in technological pedagogical content knowledge (TPCK). Computers \& Education, 52(1), 154-168. https://doi.org/10.1016/j.compedu.2008.07.006

Bağrıyanık, K. E. (2015). Fen bilgisi öğretmen adaylarının teknolojik alan bilgilerine yönelik öz yeterlik inanışları tutumları ve algıları. Yayınlanmamış Doktora Tezi. Cumhuriyet Üniversitesi: Eğitim Bilimleri Enstitüsü, Sivas.

Chai, C. S., Koh, J. H. L., \& Tsai, C. C. (2010). Facilitating preservice teachers' development of technological, pedagogical, and content knowledge (TPACK). Journal of Educational Technology \& Society, 13, 63-73.

Christanse, R. (2002). Effects of technology integration education on the attitudes of teachers and students. Journal of Research on Technology in Education, 34(4), 411-434. https://doi.org/10.1080/15391523.2002.10782359

Cohen, L., Manion, L., \& Morrison, K. (2018). Research methods in education. Milton Park, Abingdon, Oxon, England. https://doi.org/10.4324/9781315456539

Cresswell, J. W. (2012). Educational research: Planning, conducting, and evaluating quantitative and qualitative research (4th ed.). Pearson.

Ertmer, P. A., \& Ottenbreit-Leftwich, A. T. (2010). Teacher technology change: How knowledge, confidence, beliefs, and culture intersect. Journal of Research on Technology in Education, 42(3), 255-284. https://doi.org/10.1080/15391523.2010.10782551

Ertmer, P. A., Paul, A., Molly, L., Eva, R., \& Denise, W. (1999). Examining teachers' beliefs about the role of technology in the elementary classroom. Journal of Research on Computing in Education, 32(1), 54-72. https://doi.org/10.1080/08886504.1999.10782269

Erzengin, N. (2017). Fen bilimleri öğretmenlerinin teknolojik pedagojik alan bilgilerinin incelenmesi. Yayınlanmamış yüksek lisans tezi. Çanakkale Onsekiz Mart Üniversitesi, Eğitim Bilimleri Enstitüsü, Çanakkale.

Göl, M. (2016). Yönetim bilimi açısından eğitim örgütlerindeki ögrretmenlerin teknolojik pedagojik alan bilgilerinin araştırılması. Yayımlanmamış yüksek lisans tezi. İstanbul Gelişim Üniversitesi, Sosyal Bilimler Enstitüsü, İstanbul.

Gömleksiz, M. N., \& Fidan, E. K. (2011). Pedagojik formasyon programı öğrencilerinin web pedagojik içerik bilgisine ilişkin öz-yeterlik algı düzeyleri. Electronic Turkish Studies, 6(4).

Graham, C. R., Culatta, R., Pratt, M., \& West, R. (2004). Redesigning the teacher education technology course to emphasize integration. Computers in the Schools, 21(1/2), 127-148. https://doi.org/10.1300/J025v21n01_10

Graham, R. C., Burgoyne, N., Cantrell, P., Smith, L., St Clair, L., \& Harris, R. (2009). Measuring the TPACK confidence of inservice science teachers. TechTrends, 53(5), 70-79. https://doi.org/10.1007/s11528-009-0328-0

Jang, S. J., \& Tsai, M. F. (2012). Exploring the TPACK of Taiwanese elementary mathematics and science teachers with respect to use of interactive whiteboards. Computers \& Education, 59(2), 327-338. https://doi.org/10.1016/j.compedu.2012.02.003

Karadeniz, Ş., \& Vatanartıran, S. (2015). Sınıf Öğretmenlerinin Teknolojik Pedagojik Alan Bilgilerinin İncelenmesi. İlköğretim Online, 14(3), 1017-1028. https://doi.org/10.17051/io.2015.12578

Karakaya, F., \& Avgin, S. S. (2016). Investigation of teacher science discipline self-confidence about their 
technological pedagogical content knowledge (TPACK). European Journal of Education Studies.

Kazu, İ. Y., \& Erten, P. (2011). Sinıf ögretmeni adaylarının web pedagojik içerik bilgisine ilişkin görüşleri. 10. Ulusal Sınıf Öğretmenliği Eğitim Sempozyumu, Cumhuriyet Üniversitesi.

Koh, J. H. L., \& Chai, C. S. (2011). Modeling pre-service teachers. Technological pedagogical content knowledge (TPACK) perceptions: The influence of demographic factors and TPACK constructs.

Meriç, G. (2014). Fen ve teknoloji öğretmen adaylarının teknolojik pedagojik alan bilgisi konusunda öz güven seviyelerinin belirlenmesi. Eğitimde Kuram ve Uygulama, 10(2), 352-367.

Mishra, P., \& Koehler, M. J. (2006). Technological pedagogical content knowledge: A framework for teacher knowledge. Teachers
https://doi.org/10.1111/j.1467-9620.2006.00684.x

MOE. (2017). Öğretmenlik mesleği genel yeterlikleri. Öğretmen Yetiştirme ve Geliştirme Genel Müdürlüğü, Ankara. Retrieved from http://oygm.meb.gov.tr.

MOE. (2018). Fizik dersi öğretim program. Milli Eğitim Bakanlı̆̆ı, Ankara. Retrieved from http://mufredat.meb.gov.tr.

Mutluoğlu, A. (2012). İlköğretim matematik öğretmenlerinin öğretim stili tercihlerine göre teknolojik pedagojik alan bilgilerinin incelenmesi. Yayınlanmamış yüksek lisans tezi. Necmettin Erbakan Üniversitesi, Eğitim Bilimleri Enstitüsü, Konya

Öztürk, E. (2013). Sınıf öğretmeni adaylarının teknolojik pedagojik alan bilgilerinin bazı değişkenler açısından değerlendirilmesi. Uşak Üniversitesi Sosyal Bilimler Dergisi, 6(2). https://doi.org/10.12780/UUSBD163

Rahmadi, I. F., Hayati, E., \& Nursyifa, A. (2020). Comparing pre-service civic education teachers' tpack confidence across course modes. Research in Social Sciences and Technology, 5(2), 113-133. https://doi.org/10.46303/ressat.05.02.7

Raman, A. (2014). TPACK confidence of pre-service teachers in Universiti Utara Malaysia. Mediterranean Journal of Social Sciences. https://doi.org/10.5901/mjss.2014.v5n22p167

Ramos, R. A., Babasa, E. E., Vergara, I. B., Manalo, B. I., Gappi, L. L., \& Morfi, T. G. (2020) The TPACK confidence of pre-service teachers in selected philippine teacher education institutions. International Journal of Education, Psychology and Counselling, 5(37), 196-205. https://doi.org/10.35631/IJEPC.5370016

Sancar, T. H., Konokman, G. Y., \& Yelken, T. Y. (2013). Analysis of Mersin University pre-school teacher candidates' technological pedagogical content knowledge (TPACK) self-confidence. Ahi Evran University Kirsehir Education Faculty Magazine, 14(1).

Schmidt, D. A., Baran, E., Thompson, A. D., Mishra, P., Koehler, M. J., \& Shin, T. S. (2009). Technological pedagogical content knowledge (TPACK): The development and validation of an assessment instrument for preservice teachers. Journal of Research on Technology in Education, 42(2), 123-149. https://doi.org/10.1080/15391523.2009.10782544

Thompson, A. D., \& Mishra, P. (2007). Breaking News: TPCK becomes TPACK! Journal of Computing in Teacher Education, 24(2), 38-64.

Timur, B., \& Taşar, M. F. (2011). Teknolojik pedagojik alan bilgisi öz güven ölçeğinin (TPABÖGÖ) Türkçe’ye uyarlanmas1. Gaziantep University Journal of Social Sciences, 10(2), 839-856.

Tokmak, H. S., Incikabi, L., \& Ozgelen, S. (2013). An investigation of change in mathematics, science, and literacy education pre-service teachers' TPACK. The Asia-Pacific Education Researcher, 22(4), 407-415. https://doi.org/10.1007/s40299-012-0040-2

Tokmak, H., Konokman, G., \& Yanpar-Yelken, T. (2013). An investigation of Mersin University early childhood pre-service teachers' self-confidence about their technological pedagogical content knowledge (TPACK). Ahi Evran Universitesi Kirşehir Eğitim Fakultesi Dergisi, 14(1), 35-51.

Tuncer, \& Dikmen. (2018). Cinsiyetin tekno-pedagojik alan bilgisi üzerindeki etkisinin meta analiz yöntemiyle araştırılması. Firat Üniversitesi Sosyal Bilimler Dergisi, 28(1), 85-92. https://doi.org/10.18069/firatsbed.387808

Uygun, E. (2013). Learning by design: An integrated approach for technological pedagogical content knowledge development. Doctoral Dissertation. Middle East Technical University/School of Social Sciences, Ankara. 


\section{Copyrights}

Copyright for this article is retained by the author, with first publication rights granted to the journal.

This is an open-access article distributed under the terms and conditions of the Creative Commons Attribution license (http://creativecommons.org/licenses/by/4.0/). 